\title{
Fire Accidents Involving the Ignition of Sleepwear Worn by Children Under the Age of Three
}

$Q C$ 100

15753

00.815

1974

c.2

U.S. PARTMENT OF OMMERCE National Bureau of Standards 
The National Bureau of Standards ${ }^{1}$ was established by an act of Congress March 3, 1901. The Bureau's overall goal is to strengthen and advance the Nation's science and technology and facilitate their effective application for public benefit. To this end, the Bureau conducts research and provides: (1) a basis for the Nation's physical measurement system, (2) scientific and technological services for industry and government, (3) a technical basis for equity in trade, and (4) technical services to promote public safety. The Bureau consists of the Institute for Basic Standards, the Institute for Materials Research, the Institute for Applied Technology, the Institute for Computer Sciences and Technology, and the Office for Information Programs.

THE INSTITUTE FOR BASIC STANDARDS provides the central basis within the United States of a complete and consistent system of physical measurement; coordinates that system with measurement systems of other nations; and furnishes essential services leading to accurate and uniform physical measurements throughout the Nation's scientific community, industry, and commerce. The Institute consists of a Center for Radiation Research, an Office of Measurement Services and the following divisions:

Applied Mathematics - Electricity - Mechanics - Heat - Optical Physics - Nuclear Sciences $^{2}$ - Applied Radiation ${ }^{2}$ - Quantum Electronics ${ }^{3}$ - Electromagnetics ${ }^{3}$ - Time and Frequency ${ }^{3}$ - Laboratory Astrophysics ${ }^{3}$ - Cryogenics ${ }^{3}$.

THE INSTITUTE FOR MATERIALS RESEARCH conducts materials research leading to improved methods of measurement, standards, and data on the properties of well-characterized materials needed by industry, commerce, educational institutions, and Government; provides advisory and research services to other Government agencies; and develops, produces, and distributes standard reference materials. The Institute consists of the Office of Standard Reference Materials and the following divisions:

Analytical Chemistry — Polymers - Metallurgy — Inorganic Materials — Reactor Radiation - Physical Chemistry.

THE INSTITUTE FOR APPLIED TECHNOLOGY provides technical services to promote the use of available technology and to facilitate technological innovation in industry and Government; cooperates with public and private organizations leading to the development of technological standards (including mandatory safety standards), codes and methods of test; and provides technical advice and services to Government agencies upon request. The Institute consists of a Center for Building Technology and the following divisions and offices:

Engineering and Product Standards — Weights and Measures - Invention and Innovation - Product Evaluation Technology - Electronic Technology — Technical Analysis - Measurement Engineering - Structures, Materials, and Life Safety ${ }^{1}$ — Building Environment ${ }^{4}$ - Technical Evaluation and Application ${ }^{*}$ — Fire Technology.

THE INSTITUTE FOR COMPUTER SCIENCES AND TECHNOLOGY conducts research and provides technical services designed to aid Government agencies in improving cost effectiveness in the conduct of their programs through the selection, acquisition, and effective utilization of automatic data processing equipment; and serves as the principal focus within the executive branch for the development of Federal standards for automatic data processing equipment, techniques, and computer languages. The Institute consists of the following divisions:

Computer Services - Systems and Software — Computer Systems Engineering — Information Technology.

THE OFFICE FOR INFORMATION PROGRAMS promotes optimum dissemination and accessibility of scientific information generated within NBS and other agencies of the Federal Government; promotes the development of the National Standard Reference Data System and a system of information analysis centers dealing with the broader aspects of the National Measurement System; provides appropriate services to ensure that the NBS staff has optimum accessibility to the scientific information of the world. The Office consists of the following organizational units:

Office of Standard Reference Data - Office of Information Activities - Office of Technical

Publications - Library - Office of International Relations.

I Headquarters and Laboratories at Gaithersburg, Maryland, unless otherwise noted; mailing address Washington, D.C. 20234.

2 Part of the Center for Radiation Research.

Located at Boulder, Colorado 80302.

4 Part of the Center for Building Technology. 


\section{Fire Accidents Involving the Ignition of Sleepwear Worn by Children Under the Age of Three}

National Burearr of Standards

Elaine A. Tyrrell

Fire Technology Division Institute for Applied Technology

National Bureau of Standards

Washington, D.C. 20234

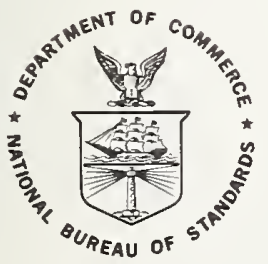

U.S. DEPARTMENT OF COMMERCE, Frederick B. Dent, Secrefary NATIONAL BUREAU OF STANDARDS, Richard W. Roberts, Director Issued February 1974 
National Bureau of Standards Technical Note 815

Nat. Bur. Stand. (U.S.), Tech. Note 815, 23 pages (Feb. 1974)

CODEN: NBTNAE 
1. INTRODUCTION . • . . . . . . . . . . . . 1

2. SLEEPWEAR IGNITIONS IN FFACTS. . . . . . . . . . . 2

2.1 Sleepwear Ignitions Involving 0-2 Year Olds. 4

3. SUMMARY OF DATA FOR SLEEPWEAR ACCIDENTS INVOLVING CHILDREN UNDER AGE 3 . . . . . . . . . . . . . 3.1 Victim's Involvement. . . . . . . . . . . 3.2 Ignition Sources. . . . . . . . . . . .

3.3 Extent of Injuries. . . . . . . . . . . .

$\cdot \cdot \cdot \cdot \cdot \cdot$

3.5 Supervision . . . . . . . . . . . . 7

3.6 Sleepwear Garment Type. . . . . . . . . . 8

3.7 Sleepwear Fiber and Fabric Analysis . . . . 8

4. CONCLUSIONS. . . . . . . . . . . . . . . 9 9

APPENDIX A. THE FLAMMABLE FABRICS ACCIDENT CASE AND TESTING SYSTEM (FFACTS). . . . . . . . . . 10

APPENDIX B. CASE HISTORIES OF 22 SLEEPWEAR FIRE

ACCIDENTS INVOLVING CHILDREN UNDER AGE 3 IN THE

FFACTS DATA BASE OF 1,964 CASES. . . . . . . . 10

REFERENCES . . . . . . . . . . . . . . 18 

FIRE ACCIDENTS INVOLVING THE IGNITION OF SLEEPWEAR WORN BY CHILDREN UNDER THE AGE OF THREE

\section{Elaine A. Tyrrell}

Accident case histories of children under age 3 involved in sleepwear fires are examined in detail. Of 434 persons involved in sleepwear ignition incidents in the NBS Flammable Fabrics Accident Case and Testing System as of January 1973, 101 were children under age $6 ; 22$ of these were children under age 3 . In 15 of these 22 accidents, the child was a victim of his own actions, while in 7 more accidents, the child played a passive role in the ignition sequence. Matches and kitchen ranges were the most frequent ignition sources found for this group of children. Seven of these small children died; the remaining 15 victims sustained burn injuries covering from one to 65 percent of their bodies. Most of the sleepwear items involved in these 22 accidents were made of cotton and 14 of these 22 items were pajamas. Children under age 3 were most frequently involved in fire accidents during the morning hours in the kitchen or bedroom. Only one child was under the supervision of an adult at the time of the accident. From the information found in the case history reports, an analysis of the severity of the injuries received by the victims was made and it was determined that the severity of the injuries received by one of the 3 infants under the age of one and 15 of the remaining 19 one- and two-year-olds probably would have been reduced if they had been afforded the protection of a flammability standard.

Key words: Accidents; burn injuries; case histories; children's sleepwear; fabric fires; FFACTS; fires; flammable fabrics; garment fires; ignition sources; standards.

\section{INTRODUCTION}

The current flammability standard for children's sleepwear, sizes $0-6 \mathrm{X}$ [1] 1 , was based on a finding [2] that children ages 0-5 were exposed to an unreasonable risk of death or in-

$l_{\text {Figures in brackets indicate the literature references at the }}$ end of this paper. 
jury from fire incidents involving their sleepwear. This finding resulted from laboratory studies of garments and fabrics, and from an analysis of accident data on fabric product fires. These data indicated that children ages 0-5 were involved in sleepwear fires more frequently than persons from any other age group.

Official petitions from various organizations challenged the inclusion of sleepwear for the very young in the standard. In light of questions arising from these petitions, the National Bureau of Standards Flammable Fabrics Accident Case and Testing System (FFACTS) ${ }^{2}$ was searched for accidents involving the ignition of sleepwear worn by 0-2 year olds. This report is a summary of information from those accidents and as such provides background documentation for the inclusion of very young children in the standard.

\section{SLEEPWEAR IGNITIONS IN FFACTS}

From a FFACTS data base of 1,964 accident cases as of January 1973, 434 were found which involved persons clothed in sleepwear apparel3. Figure 1 shows the age distribution of these victims, who, for purposes of analysis, have been arbitrarily divided into six age groups ${ }^{4}$, roughly representing six types of behavior patterns. The age group most frequently involved in sleepwear accidents was children from 0 through 5 years of age. They represent 101 (23 percent) of the persons involved in sleepwear accidents. In comparison, 83 (19 percent) of the victims of sleepwear fires were adults 66 years old and over; another 83 ( 19 percent) were adults $46-65$ years old; 80 ( 19 percent) were children $6-12$ years old; 67 ( 16 percent) were young adults, ages 21-45; and 18 ( 4 percent) were youth, ages 13-20. In all age groups, females were injured more often than males.

2 See Appendix A for a description of the FFACTS data base.

${ }^{3}$ In these 434 accidents, sleepwear garment contamination with flammable liquids was reported in 22 of the accidents, one of which involved a child under the age of three. In addition, sleepwear garments which did not ignite were reported in 21 of the 434 accidents, 2 of which involved children under the age of three.

${ }^{4}$ Two of the victims were excluded from the age groupings as their ages were unknown. 
AGE DISTRIBUTION FOR SLEEPWEAR ACCIDENTS BY AGE GROUPS

(FFACTS, I,964 CASE DATA BASE)

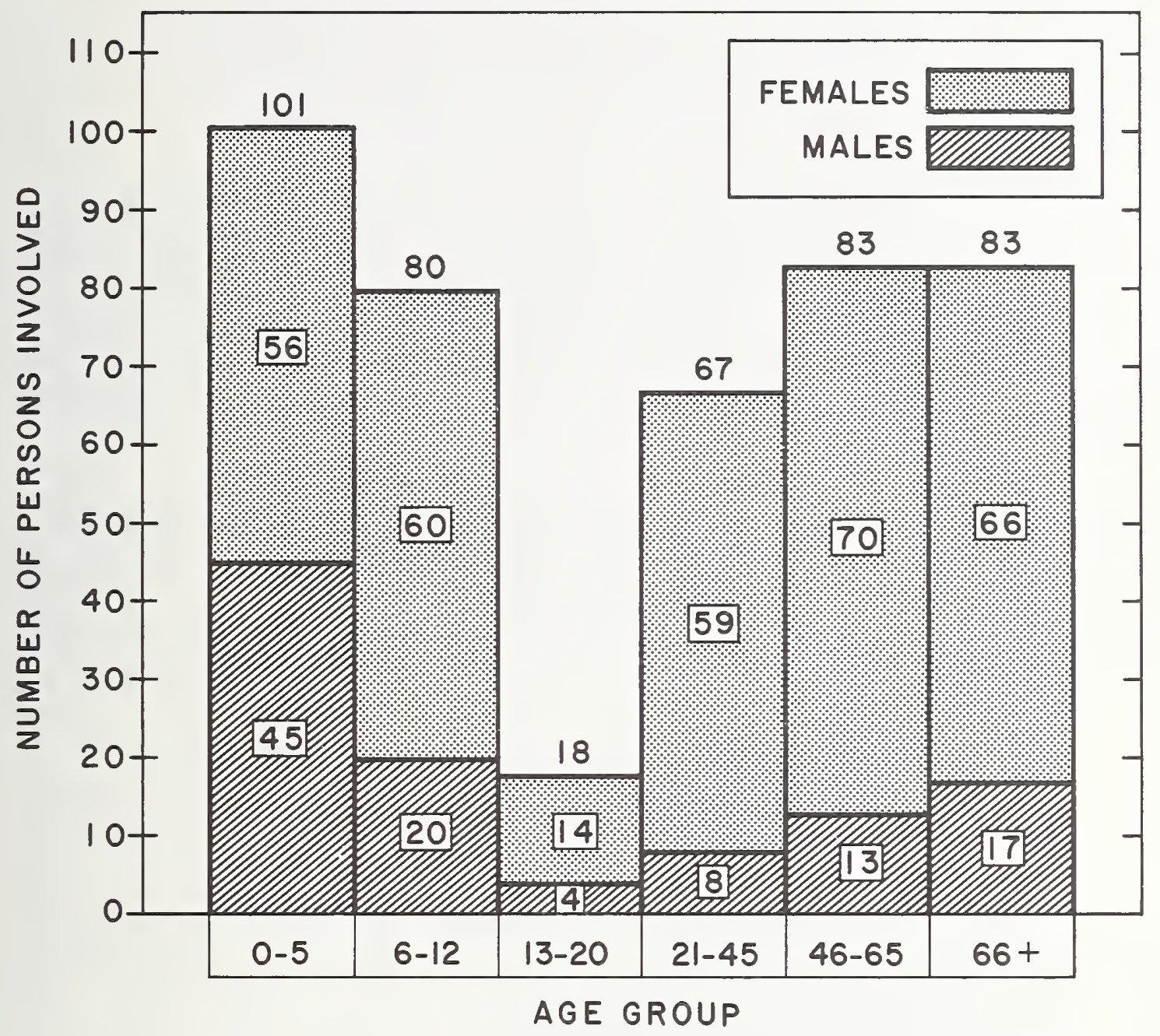

Figure 1. Age distribution of persons involved in FFACTS sleepwear accidents (including 22 cases involving flammable liquids and 21 cases in which sleepwear garments did not ignite). 


\subsection{Sleepwear Ignitions Involving 0-2 Year Olds}

of the 101 children ages 0-5 involved in sleepwear accidents, 22 were under the age of 3 (fig. 2). Three of these children were under the age of one; 6 were one-year-olds, and the remaining 13 victims were two-year-olds. Half of the 22 victims were males and half were females.

Children under age three are of particular interest because they are the least mobile and knowledgeable of the group of children presently covered by the children's sleepwear standard. They lack well-developed motor skills, communicative abilities, and learned responses (e.g. common sense in fire situations) and thus are dependent on others for their welfare and existence. This is especially true of children under the age of one.

The following sections of this report describe the circumstances surrounding the involvement of children under the age of 3 in fires which ignited their sleepwear. A summary of key aspects of the 22 accidents is given in table 1 . In addition, detailed descriptions of each of the accidents, as compiled from case histories, are provided in Appendix B.

\section{SUMMARY OF DATA FOR SLEEPWEAR ACCIDENTS INVOLVING CHILDREN UNDER AGE 3}

\subsection{Victim's Involvement}

In each of the 3 accidents involving children under age one, the infant was sleeping and played a passive role in the ignition sequence; that is, each was a helpless bystander. In 15 of the remaining 19 accidents involving one- and two-yearolds, the child was a victim of his own actions; in 2 other accidents, the child was involved in the ignition process by an older sibling; and in the remaining 2 accidents, the child was a helpless bystander.

\subsection{Ignition Sources}

Matches and kitchen ranges were the most frequent ignition sources for this age group of children, accounting for 17 of the 22 ignitions. Playing with matches resulted in 9 injuries. Only the two-year-olds ignited their own sleepwear with matches; younger children were involved by the actions of older siblings. Two of the 3 infants under the age of one were injured as a result of siblings, ranging in age from 2 to 4 years, playing with matches or a lighter. Seven of the twoyear-olds were injured while playing with matches; another two- 
FREQUENCY OF SLEEPWEAR ACCIDENTS BY AGES FOR AGE GROUP 0-5 (FFACTS, 1,964 CASE DATA BASE)

O- UNDER ONE YEAR OF AGE

I - FIRST BIRTHDAY UP TO SECOND BIRTHDAY

2-SECOND BIRTHDAY UP TO THIRD BIRTHDAY

3-THIRD BIRTHDAY UP TO FOURTH BIRTHDAY

4-FOURTH BIRTHDAY UP TO FIFTH BIRTHDAY

5 -FIFTH BIRTHDAY UP TO SIXTH BIRTHDAY

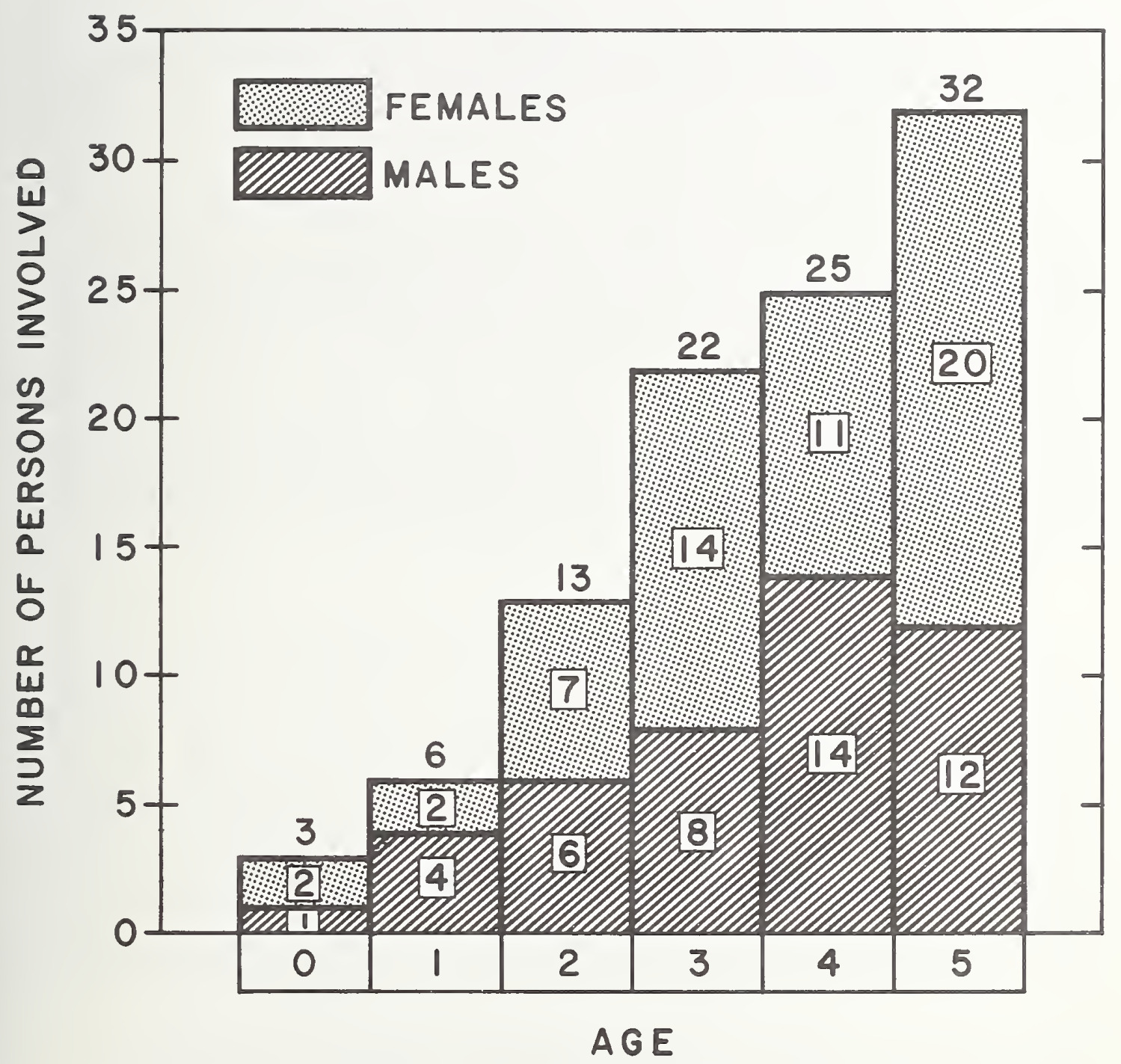

Figure 2. Frequency of sleepwear accidents for age group 0-5 (includes accidents involving flammable liquids and accidents in which garments did not ignite). 


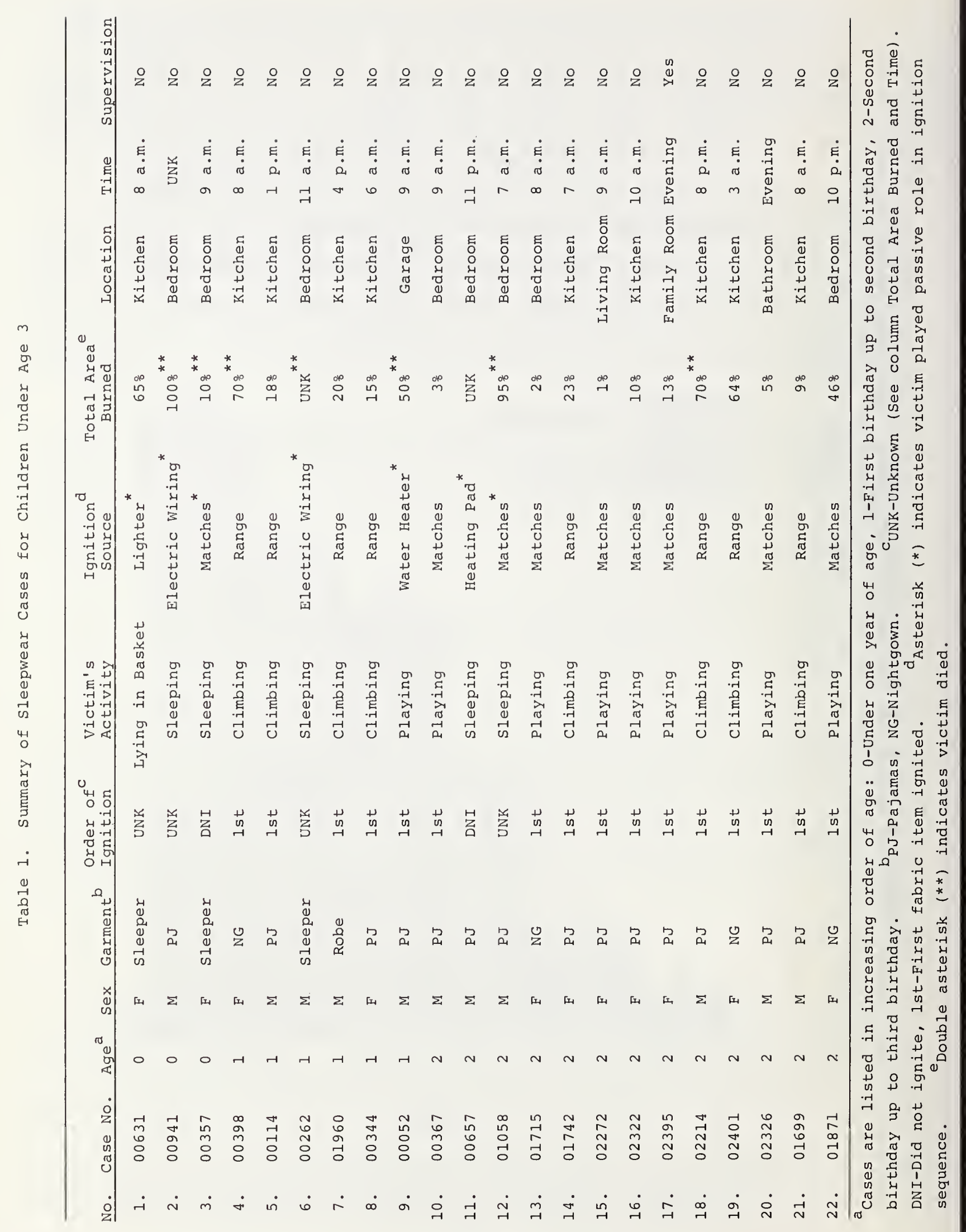


year-old was injured while sleeping, as a result of his fouryear-old brother playing with matches. None of the one-yearolds was injured from playing with matches or lighters, an activity that requires the comparatively greater dexterity and mobility of a two-year-old.

Climbing on kitchen ranges resulted in 8 injuries. Four of the 6 one-year-olds were injured while climbing on a kitchen range, either by accidently turning on one of the surface units or by sitting on the heating elements and playing with the control knobs. Only 4 of the 14 two-year-olds were injured while involved in this type of activity.

of the 4 remaining victims, 3 (an infant, a one-year-old, and a two-year-old) were injured as the result of fires due to faulty electrical wiring. The remaining one-year-old was injured as the result of his three-year-old brother playing with gasoline too close to a gas water heater.

\subsection{Extent of Injuries}

Two of the victims under the age of one died of smoke inhalation and burns; the third infant suffered burns to 65 percent of her body and amputation of both feet. Five of the oneand two-year-olds died as a result of their injuries; one from asphyxiation and burns, the other 4 from burns covering 50-95 percent of their bodies. Of the remaining 14 victims, 7 sustained burns covering 1-10 percent of their bodies, 5 sustained burns covering 13-23 percent of their bodies, and 2 sustained. burns covering 46 and 64 percent of their bodies, respectively.

\subsection{Time and Location of Incident}

Children in the 0-2 age group were involved in fire accidents most frequently during the morning hours between 8 and $10 \mathrm{a} . \mathrm{m}$. A few isolated accidents involving only two-year-olds occurred during the evening hours up to $11 \mathrm{p} . \mathrm{m}$. Accidents occurred more often in the kitchen or bedroom. Ten of the 22 accidents occurred in the kitchen, 7 during the morning hours and 3 during the afternoon and evening. Eight of the 22 accidents occurred in the bedroom, 5 during the morning hours and 2 in the evening. Time of day was not known for one of the accidents reported to have taken place in the bedroom.

\subsection{Supervision}

Only one of the 22 victims was under the supervision of an adult at the time of the accident. In this case, the mother 
of the victim was present in the same room but had her back turned when the child struck a match that ignited her pajamas. The most frequently reported activities of the parents at the time of ignition were sleeping, preparing meals, dressing, or talking, either on the telephone or to other adults in the house.

\subsection{Sleepwear Garment Type}

of the sleepwear items found in this age group, pajamas were the most prevalent. Of the 14 pajamas involved in accidents, one was worn by an infant (male) and 13 by the one- and two-year-olds ( 8 males and 4 females). Even though pajamas are usually fitted garments which makes them less susceptible to ignition from accidental contact with flame sources, the circumstances in 13 of these accidents permitted ignition regardless of the close fit of the garments. Eleven of these pajamas were first-to-ignite items and 2 were conflagration cases. In the remaining accident, the pajamas did not ignite but only scorched.

The 4 nightgowns involved in accidents were all the first items to ignite and were worn by female one- and two-year-olds. Three accidents involving sleepers were found (2 female infants and one male one-year-old). Two of these sleepers were conflagration cases and one sleeper did not ignite. Only one accident was found which involved a robe (male one-year-old), and it was a first-to-ignite item.

\subsection{Sleepwear Fiber and Fabric Analysis}

In 10 of the 22 accidents, sleepwear remnants were submitted for a laboratory analysis of fiber content and fabric construction. For 11 more accidents, some or all of this information was gleaned from case history reports. Most of these garments were found to be made of cotton. Of the garments tested in the laboratory, 2 pajamas, one nightgown, and the robe were found to be 100 percent cotton flannelette; 2 pajamas and one nightgown were found to be 100 percent cotton knit; one pajamas was found to be 100 percent cotton, plain weave; one sleeper was found to be 100 percent cotton knit, napped; and another sleeper was found to be approximately $75 / 25$ percent cotton-nylon knit pile. From the case history reports, it was learned that 4 pajamas and 2 nightgowns were cotton flannel, one pajamas was cotton flannelette, 2 pajamas were cotton, one pair of pajamas was flannel, and one sleeper was made of terry. For the remaining pajamas incident, no garment remnant was submitted for testing and no mention was made in the case history report of either the fiber content or fabric construction. 
In the FFACTS data base, children in the 0-5 age group were involved in sleepwear fires more frequently than persons from any other age group. Twenty-two of the 101 children in this age group were under the age of 3. Because this 0-2 yearold segment of the population is the least mobile, knowledgeable, and self-sufficient, they are frequently the helpless victims of the hazardous actions of others or those of their own. Children this young are extremely vulnerable to accidents involving the ignition of their clothing, which, due to their age, frequently means sleepwear items. These sleepwear items are made from the same fabrics used for the sleepwear of older children and thus exhibit the same flammability characteristics.

From the circumstances of the accidents described in the case history reports, it is possible to estimate what effect a flammability standard would have had on the outcome of the accidents. If the area of body burned seemed to be a direct consequence of the proximity of burning fabric, it was judged that the severity of the injury sustained probably would have been reduced if the protection of a flammability standard had been afforded. This criterion is met by the cases of one of the 3 infants under the age of one and 15 of the remaining 19 one- and two-year-olds. Thus 16 of the 22 children probably would have benefited from a sleepwear flammability standard. These 16 cases are marked in Appendix B by an asterisk preceding the case numbers. 


\section{APPENDIX A. THE FLAMMABLE FABRICS ACCIDENT CASE AND TESTING SYSTEM (FFACTS)}

The Flammable Fabrics Accident Case and Testing System (FFACTS) is comprised of reports of fire incidents involving fabric products and laboratory test results of any fabric remains which may accompany these reports. These accident reports, along with any available fabric remnants, are forwarded to the NBS Fire Technology Division by Consumer Product Safety Commission (CPSC) field investigators and other participating organizations for testing and evaluation. Processing of the reports and fabric samples accepted for FFACTS includes the analysis of fabric samples for fabric weight, construction, composition and flammability characteristics, and the coding and computerization of up to 130 different data elements for each incident. Incidents chosen for FFACTS are not selected on a statistical basis, and therefore do not constitute a statistically representative sample of all fabric fire accidents in the United States. However, they do represent events investigated without known preference and therefore may be roughly representative of incidents reported to the agencies from which the CPSC and others obtain accident data.

APPENDIX B. CASE HISTORIES OF 22 SLEEPWEAR FIRE ACCIDENTS INVOLVING CHILDREN UNDER AGE 3 IN THE FFACTS DATA BASE OF 1,964 CASES $^{1}$

\section{*1. CASE NO. 00631}

A six-week-old female wearing a sleeper (reported to be terrycloth) and rubber pants was wrapped in a blanket and placed in a wicker basket on the kitchen table. The table was covered with a plastic tablecloth. It was 8 o'clock in the morning and the infant's two-year-old sister was playing in the area. There was no adult supervision present at the time of the ignition. It was theorized that the two-year-old found a lighter and lit it near the wicker basket. She became frightened and dropped it on the table where it ignited the plastic tablecloth which in turn ignited the wicker basket and the infant's clothing. The mother smelled smoke and rushed downstairs to find the infant engulfed in flames. She went into shock and was unable to do anything except scream. The

$1_{\text {An }}$ asterisk (*) preceding a case number indicates that the victims probably would have benefited from a sleepwear flammability standard. 
father, who had been sleeping, rushed downstairs, took the infant out of the basket and wrapped her in a nylon jacket to extinguish the flames. All of the victim's clothing was burned. The victim was hospitalized with burns covering 65 percent of her body: third degree burns from the waist down and on the left arm, and second degree burns on the left cheek. The burns necessitated the amputation of both feet.

\section{CASE NO. 00941}

A three-month-old male wearing pajamas was left unattended in a bassinette in a trailer. An electric clother dryer, in use at the time, overloaded a circuit which started a fire in the wall paneling. The bassinette was contiguous to the wall paneling where the ignition occurred. The time of the ignition of the injury is unknown. The mother was visiting a neighbor when the fire started and by the time she discovered the fire, she was unable to rescue the infant. The fire department extinguished the flames. Damage was restricted to the wall panel, floor, and carpet in the area of the bassinette which was also destroyed. The victim's death was attributed to asphyxiation and burns covering his entire body with third degree burns covering 90 percent of his body.

\section{CASE NO. 00357}

A seven-month-old female wearing a sleeper of approximately $75 / 25$ percent cotton-nylon knit pile was asleep in a plastic coated wood crib. The infant was lying on a plastic mattress cover which presumably was covered with a blanket or sheet. No supervision was present. It was about 9 o'clock in the morning. The infant's four-year-old brother was playing with matches and started a fire on his own bed which was across the room from the infant's crib. The boy became frightened and left the room without notifying his mother who was asleep on the couch in the living room. The fire was discovered approximately ten or fifteen minutes later by a neighbor. The fire department was summoned to extinguish the flames. The room was filled with smoke, but the fire was restricted to the bed. Although the fire did not reach the infant's crib, the heat it generated softened the plastic which surrounded the victim. As a result, the infant suffered first and second degree burns on her face and head and second degree burns on her hands due to the hot plastic. Her pajamas were scorched, but did not ignite. The victim was taken to the hospital by her mother and the neighbor, but pronounced dead on arrival from smoke inhalation. On a previous occasion, the brother had burned the baby's leg with a match. 
A fifteen-month-old female wearing a 100 percent cotton knit nightgown and wet diaper pushed her high chair over to the electric range and climbed onto the range, apparently in an attempt to reach some brightly colored pills on the back of the range. It was about $8: 20 \mathrm{a} \cdot \mathrm{m}$. and her parents were upstairs dressing for work. Only the victim's four-year-old brother was present in the kitchen. It is speculated that in trying to reach the pills the child rested her hand on the control knob for the back burner and turned it on. The heat from the coil ignited her nightgown. The control knobs, located on the back panel of the range, were tested later and it was found that they need only be turned slightly to activate the heating elements. Screams from the victim eventually brought the mother downstairs. She saw the baby engulfed in flames and immediately set her on the floor and put out the fire with her hands. The victim was rushed to the hospital where she died approximately eight hours later. She suffered second and third degree burns to 70 percent of her body. She suffered no burns around the buttocks as she was protected with wet diaper she was wearing.

\section{*5. CASE NO. 00114}

An eighteen-month-old male wearing pajamas (reported to be cotton flannel) climbed onto an electric range about one p.m. While his father was asleep on the couch. While playing with the control knobs, located on the back of the range, he managed to turn on the oven and the right front burner on high. The smoke generated by the plastic handle of a skillet left in the oven awoke the father. He heard the victim crying in the kitchen and found his son sitting on the back of the range with his legs between the two front burners and the left pajama leg burning. The father smothered the flames with his hands. The victim suffered burns which covered 18 percent of his body with third degree burns on the sole of his right foot, calf of his left leg, and lower portion of his buttocks; second degree burns on one toe and the side of his left foot; and first degree burns on his face, arms, and back.

\section{CASE NO. 00262}

An eighteen-month-old male wearing a cotton polo shirt, cotton diapers and rubber pants under a 100 percent cotton knit sleeper, napped, was sleeping in a crib in an unfinished basement. There was no adult supervision present. At about 11:30 a.m., an extension cord, which was draped across the room and over the baby's crib, shorted at a spliced spot and fell into 
the crib. Pennies had been placed previously in the fuse box and the multiple outlet into which the heavy duty extension cord had been plugged also contained cords from the television which was playing and a space heater which was turned on high. It was theorized that sparks from the extension cord fell into the crib, ignited the nylon blanket or cover sheet, and ultimately the baby's clothes. The victim's mother and grandmother were upstairs talking when the ignition occurred. They thought they heard a muffled cry from the baby, but hearing no further sounds, forgot about the cries. Ten to fifteen minutes later, the two women smelled smoke and went down into the basement. They saw that the baby was burned badly and both of them became hysterical. A neighbor, hearing the screams and seeing the smoke pouring from the basement door, entered the basement. The fire had almost burned itself out and was only partially smoldering. When the fire reached the baby, it had set his back on fire and he probably rolled onto his stomach which stopped the fire from burning the front of his pajamas. He had pulled himself to his knees, perhaps trying to get out of the crib. He was found crouched on his knees with his head toward the wall at the extreme end of the crib, away from the source of the fire. Mouth to mouth resuscitation was attempted on the scene by a fireman and the baby was rushed to the hospital where he was pronounced dead on arrival. Death was reported to be caused by smoke inhalation. The extent of the baby's burns were not reported.

\section{*7. CASE NO. 01960}

A nineteen-month-old male wearing a 100 percent cotton flannelette robe and a wet disposable diaper moved a chair next to the electric range and climbed onto it about $4: 30 \mathrm{p} . \mathrm{m}$. while his father was asleep on the couch and an older brother was dressing in his bedroom. The child sat on a coil while he played with the control knobs on the back of the range. He turned on three of the surface units, one of which ignited his bathrobe. The victim's screams brought the brother to the kitchen. Seeing his baby brother sitting on the range with his clothes on fire, he ran to the living room to awaken his father who was delayed in responding as he had to locate his eyeglasses. The father pulled the child to the floor and smothered the flames with a terrycloth towel. The victim was hospitalized for approximately three months with 15 percent second degree and 5 percent third degree burns on his body. One week earlier the victim's mother had placed him on the counter next to the range. The victim pushed the control knob, turning one of the surface units to a high setting and touched the coil, burning his left index finger. 
A twenty-month-old female wearing pajamas (reported to be cotton) and a wet double diaper woke up about 6:30 a.m., climbed out of her crib and went into the kitchen. Apparently. she noticed a bowl of apples on top of the electric range and attempted to reach them by climbing onto the range from a chair. She sat down on the large left front burner with her leg folded underneath her to eat the apple. As she sat down, she apparently hit the control knob and turned the burner on high. The heat may not have been felt initially by the victim because of the insulation provided by her wet diapers, but the victim's pajamas ignited. The parents were awakened by the screams of their five-year-old daughter who found the baby with her clothes in flames. The father removed the baby from the range and smothered the flames by throwing himself over her body on the floor. The burns were treated with cold water and the baby was rushed to the hospital. The victim was hospitalized for approximately two months with 12 percent second degree and 3 percent third degree burns on her lower legs and left foot.

\section{CASE NO. 00052}

A twenty-two-month-old male wearing a pajama top and training pants (both reported to be cotton) was playing with his three-year-old brother on a small patio which was contiguous to the garage door at about 8:40 a.m. The three-year-old apparently spilled some gasoline from a glass jug his father had left on the floor outside the garage door. The gasoline was ignited by the pilot light from a gas water heater, also located outside, between the garage and the house. Although the clothing of both youngsters was saturated with gasoline, only the clothing of the one-year-old ignited. Screams from both boys brought the mother who tore off the victim's clothing, extinguishing the flames. The pajama top was almost completely consumed, but the training pants afforted some protection to those areas of the body that the pants covered. The victim was hospitalized with first, second, and third degree burns covering 50 percent of his body. He died several days later.

\section{*10. CASE NO. 00367}

A two-year-old male wearing pajamas (reported to be cotton flannel) found a book of matches in the pocket of a bathrobe. At about 9 ' clock in the morning, he took them to his bed and lit one which ignited his pajama top. The victim's uncle and grandmother heard him cry out and ran to the child's room where 
they found the pajama top engulfed in flames. The uncle smothered the flames with a blanket and they removed the burned pajamas from the victim. The child was hospitalized for six weeks with second and third degree burns on his chest and abdomen which required skin grafts.

\section{CASE NO. 00657}

A two-year-old male wearing pajamas (reported to be flannel) was put to bed with his brother in their mother's bed at about 11 p.m. The mother was away from the bedroom for awhile. When she returned, she found the bed in flames, apparently from faulty wiring in a heating pad. She pulled the two boys from the bed and called the fire department. The mother later noticed that the two-year-old had been burned. The victim suffered first and second degree burns on a small area of his back although the pajamas he was wearing did not ignite but only scorched in one small area.

\section{CASE NO. 01058}

A two-year-old male wearing 100 percent cotton pajamas was asleep in his bed when a fire broke out in the house around 7:30 a.m., probably as the result of a four-year-old brother playing with matches. The fire moved from the brother's bed to the victim's bed which was in the same room, and in the process, consumed a large part of the plywood wall paneling and all of the linoleum flooring except for a section underneath a dresser. The mother rescued the four-year-old and an infant, both of whom escaped injury. The two-year-old was hospitalized with second and third degree burns over 95 percent of his body. Only the diaper area was not burned. The victim died five hours later. The mother also received burns covering approximately 50 percent of her body; 10 percent were third degree burns.

\section{*13. CASE NO. 01715}

A two-year-old female wearing a 100 percent cotton flannelette nightgown was playing with matches with her two-yearold brother about $8: 30 \mathrm{a} . \mathrm{m}$. There was no adult supervision present. In the course of answering the telephone, the child's grandmother noticed the child sitting on her bed with her nightgown on fire. The grandmother dropped the telephone, rushed into the bedroom and beat out the flames on the nightgown with her hands. The victim was rushed to the hospital by the mother and grandmother where she received treatment for second degree burns on her right thigh and the right side of her abdomen. 
A two-year-old female wearing a pajama shirt (reported to be cotton flannel) and panties (reported to be silk) was playing with her 3 siblings about 7 'clock in the morning, about an hour before the parents normally arise. The children were apparently playing on or around the gas range in the kitchen when the pilot light from one of the burners ignited the loose pajama shirt the victim was wearing. The child ran to her parents' bedroom with her pajamas in flames. The father rolled her on the floor to extinguish the flames. The panties had melted in the front. The father may have applied a petroleum jelly to the burned areas before taking her to the hospital. The victim was treated for first, second, and third degree burns to the chest, neck, arms and genitals, a total area covering approximately 23 percent of her body. At the time of the investigation, her condition was complicated by a stress ulcer, heart problems, and breathing problems which necessitated a tracheotomy.

\section{*15. CASE NO. 02272}

A two-year-old female wearing knit pajamas of 100 percent cotton was playing in the living room with her four-year-old sister about 8:58 a.m. They found some matches on the mantle. The victim lit one which ignited the leg of her pajamas. The mother discovered the child with her pajama leg burning and extinguished the flames. She took the victim to the hospital where she was treated and released with second and third degree burns to her thigh, an area covering approximately one percent of her body.

\section{*16. CASE NO. 02322}

A two-year-old female wearing pajamas (reported to be cotton flannel) was playing with matches and cigarettes in the kitchen about 10:30 a.m. She lit one of the matches and ignited her pajamas. Her mother extinguished the flames. The victim was treated and released with second and third degree burns covering her chest and shoulders, an area representing approximately 10 percent of her body.

\section{*17. CASE NO. 02395}

A two-year-old female wearing pajamas (reported to be cotton flannelette) was sitting in a chair in the family room one evening. The victim's mother was present in the room when the ignition occurred but had her back turned to the child. 
The victim struck a match which ignited her pajamas. The mother turned when the child screamed and extinguished the flames. The victim was hospitalized with third degree burns covering approximately 13 percent of her body.

\section{*18. CASE NO. 02214}

A two-and-a-half-year-old male wearing flannelette pajamas of 100 percent cotton and disposable diapers climbed onto an electric range in the kitchen about $8 \mathrm{p} . \mathrm{m}$. and turned on a burner. The pajamas ignited and the boy ran to his mother engulfed in flames. The mother extinguished the flames by putting her son under the shower in the bathroom. The pajamas were completely consumed, but the disposable diaper protected the body area that it covered. The child was hospitalized with first, second, and third degree burns covering approximately 70 percent of his body. He died approximately nine weeks later.

\section{*19. CASE NO. 02401}

A two-and-a-half-year-old female wearing a nightgown (reported to be cotton flannel) and an undershirt (reported to be cotton) woke up around $3: 30 \mathrm{a} . \mathrm{m}$. and went to the kitchen. She chimbed on the counter adjacent to the electric range and began playing with sugar, salt, coffee, etc., and apparently the control knobs on the range. She turned on a burner and ignited her nightgown which was consumed completely. The undershirt was consumed partially. The victim was hospitalized with second and third degree burns covering approximately 65 percent of her body. She died five days later.

\section{*20. CASE NO. 02326}

A two-year-ten-month-old male wearing a knit pajama top of 100 percent cotton and a knit undershirt of 100 percent cotton was playing in the bathtub one evening when he found a book of matches. Pretending a hairpin was a cigarette, he placed it in his mouth and attempted to light it. The lighted match dropped into his lap and ignited the pajama top. Hearing the victim scream, the mother ran to the bathroom and tried to extinguish the flames with her hands. When this did not work, she grabbed a towel and wrapped him in it. The victim was treated for second degree burns covering approximately 5 percent of his body. 
A two-year-eleven-month-old male wearing pajamas of 100 percent cotton flannelette was playing in the kitchen at about 8:30 a.m. while his parents were elsewhere in the house. The boy apparently turned on one of the heating elements on the electric range and was trying to turn it off again when his pajama top came in contact with the hot coils and ignited. The victim's screams brought the father to the kitchen where he found the pajama top in flames. The father put the flames out with his hands. The pajamas were removed, and the victim was wrapped in a cold wet towel by his mother. The victim was hospitalized with second and third degree burns to the left side of his chest and left arm, an area covering approximately 9 percent of his body.

\section{*22. CASE NO. 01817}

A two-year-eleven-month-old female, wearing a new nightgown (reported to be cotton flannel), an undershirt (reported to be cotton), cotton diapers with plastic pants, and socks, had been put to bed in a crib at approximately 10:30 p.m. The family was spending the night with a relative and the child was sleeping in her uncle's bedroom. From her crib, the victim was apparently able to reach a lighter or some matches on the dresser. The parents were visiting in the living room downstairs when they heard the victim crying. As many people were in the living room talking, the parents at first thought the crying was that of their three-month-old infant, but soon realized that it was the victim. When the father reached the victim, it appeared as though the entire nightgown was in flames. He smothered the flames with the crib blanket and carried her downstairs where she was immersed in cold water in the bathtub. The socks did not burn, nor did the diapers and plastic pants, which were only scorched in a few places, thus protecting the body areas they covered. The victim was hospitalized with third degree burns covering approximately 46 percent of her body.

\section{REFERENCES}

[1] The Standard for the Flammability of Children's Sleepwear, DoC FF3-71, Federal Register, Vol. 37, No. 141 (July 21, 1972), 14524-14632 (Revised).

[2] Children's Wearing Apparel, Notice of Finding That Flammability Standard or Other Regulation May Be Needed and Institution of Proceedings, Federal Register, Vol. 35, No. 17 (Jan. 24, 1970), 1019-1020. 
NBS.114A (REV. 7.73$)$

\begin{tabular}{|c|c|c|c|}
\hline $\begin{array}{l}\text { U.S. DEPT. OF COMM. } \\
\text { BIBLIOGRAPHIC DATA } \\
\text { SHEET }\end{array}$ & $\begin{array}{l}\text { 1. PUBLICATION OR REPORT NO. } \\
\text { NBS TN-815 }\end{array}$ & $\begin{array}{l}\text { 2. Gov't Accession } \\
\text { No. }\end{array}$ & 3. Recipient's Accession No. \\
\hline \multirow{2}{*}{\multicolumn{3}{|c|}{$\begin{array}{l}\text { 4. TITLE AND SUBTITLE: } \\
\text { Fire Accidents Involving The Ignition of Sleepwear Worn } \\
\text { By Children Under The Age Of Three }\end{array}$}} & $\begin{array}{l}\text { 5. Publication Date } \\
\text { February } 1974\end{array}$ \\
\hline & & & 6. Performing Organization Code \\
\hline \multicolumn{3}{|l|}{$\begin{array}{l}\text { 7. Author(S) } \\
\text { Elaine A. Tyrrell }\end{array}$} & 8. Performing Organ. Report No. \\
\hline \multirow{2}{*}{\multicolumn{3}{|c|}{$\begin{array}{l}\text { 9. PERFORMING ORGANIZATION NAME AND ADDRESS } \\
\text { NATIONAL BUREAU OF STANDARDS } \\
\text { DEPARTMENT OF COMMERCE } \\
\text { WASHINGTON, D.C. } 20234\end{array}$}} & $\begin{array}{l}\text { 10. Project/Task/Work Unit No. } \\
4903235\end{array}$ \\
\hline & & & 11. Contract/Grant No. \\
\hline \multirow{3}{*}{\multicolumn{3}{|c|}{ 12. Sponsoring Organization Name and Complete Address (Street, City, State, ZIP) }} & $\begin{array}{l}\text { 13. Type of Report \& Period } \\
\text { Covered }\end{array}$ \\
\hline & & & Final \\
\hline & & & 14. Sponsoring Agency Code \\
\hline
\end{tabular}

15. SUPPLEMENTARY NOTES

16. ABSTRACT (A 200-word or less factual summary of most significant information. If document includes a significant bibliography or literature survey, mention it here.)

Accident case histories of children under age 3 involved in sleepwear fires are examined in detail. Of 434 persons involved in sleepwear ignition incidents in the NBS Flammable Fabrics Accident Case and Testing System as of January 1973, 101 were children under age 6; 22 of these were children under age 3. In 15 of these 22 accidents, the child was a victim of his own actions, while in 7 more accidents, the child played a passive role in the ignition sequence. Matches and kitchen ranges were the most frequent ignition sources found for this group of children. Seven of these small children died; the remaining 15 victims sustained burn injuries covering from one to 65 percent of their bodies. Most of the sleepwear items involved in these 22 accidents were made of cotton and 14 of these 22 items were pajamas. Children under age 3 were most frequently involved in fire accidents during the morning hours in the kitchen or bedroom. Only one child was under the supervision of an adult at the time of the accident. From the information found in the case history reports, an analysis of the severity of the injuries received by the victims was made and it was determined that the severity of the injuries received by one of the 3 infants under the age of one and 15 of the remaining 19 one- and two-year-olds probably would have been reduced if they had been afforded the protection of a flammability standard.

17. KEY WORDS (six to twelve entries; alphabetical order; capitalize only the first letter of the first key word unless a proper name; separated by semicolons)

Accidents; burn injuries; case histories; children's sleepwear; fabric fires; FFACTS; fires; flammable fabrics; garment fires; ignition sources; standards.
18. AVAILABILITY
X Unlimited

For Official Distribution. Do Not Release to NTIS

Order From Sup. of Doc., U.S. Government Printing Office

Washington, D.C. 20402, SD Cat. No.C13.

\begin{tabular}{|c|c|}
\hline $\begin{array}{l}\text { 19. SECURITY CLASS } \\
\text { (THIS REPORT) } \\
\text { UNCL ASSIFIED }\end{array}$ & $\begin{array}{l}\text { 21. NO. OF PAGES } \\
23\end{array}$ \\
\hline $\begin{array}{l}\text { 20. SECURITY CLASS } \\
\text { (THIS PAGE) } \\
\text { UNCLASSIFIED }\end{array}$ & $\begin{array}{r}\text { 22. Price } \\
.60\end{array}$ \\
\hline
\end{tabular}

Order From National Technical Information Service (NTIS) Springfield, Virginia 22151 



\section{NBS TECHNICAL PUBLICATIONS}

\section{PERIODICALS}

JOURNAL OF RESEARCH reports National Bureau of Standards research and development in physics, mathematics, and chemistry. Comprehensive scientific papers give complete details of the work, including laboratory data, experimental procedures, and theoretical and mathematical analyses. Illustrated with photographs, drawings, and charts. Includes listings of other NBS papers as issued.

Published in two sections, available separately:

\section{- Physics and Chemistry (Section A)}

Papers of interest primarily to scientists working in these fields. This section covers a broad range of physical and chemical research, with major emphasis on standards of physical measurement, fundamental constants, and properties of matter. Issued six times a year. Annual subscription: Domestic, $\$ 17.00$; Foreign, $\$ 21.25$.

\section{- Mathematical Sciences (Section B)}

Studies and compilations designed mainly for the mathematician and theoretical physicist. Topics in mathematical statistics, theory of experiment design, numerical analysis, theoretical physics and chemistry, logical design and programming of computers and computer systems. Short numerical tables. Issued quarterly. Annual subscription: Domestic, $\$ 9.00$; Foreign, $\$ 11.25$.

\section{DIMENSIONS, NBS}

The best single source of information concerning the Bureau's measurement, research, developmental, cooperative, and publication activities, this monthly publication is designed for the layman and also for the industry-oriented individual whose daily work involves intimate contact with science and technology - for engineers, chemists, physicists, research managers, product-development managers, and company executives. Annual subscription: Domestic, $\$ 6.50$; Foreign, $\$ 8.25$.

\section{NONPERIODICALS}

Applied Mathematics Series. Mathematical tables, manuals, and studies.

Building Science Series. Research results, test methods, and performance criteria of building materials, components, systems, and structures.

Handbooks. Recommended codes of engineering and industrial practice (including safety codes) developed in cooperation with interested industries, professional organizations, and regulatory bodies.

Special Publications. Proceedings of NBS conferences, bibliographies, annual reports, wall charts, pamphlets, etc.

Monographs. Major contributions to the technical literature on various subjects related to the Bureau's scientific and technical activities.

National Standard Reference Data Series. NSRDS provides quantitative data on the physical and chemical properties of materials, compiled from the world's literature and critically evaluated.

Product Standards. Provide requirements for sizes, types, quality, and methods for testing various industrial products. These standards are developed cooperatively with interested Government and industry groups and provide the basis for common understanding of product characteristics for both buyers and sellers. Their use is voluntary.

Technical Notes. This series consists of communications and reports covering both other-agency and NBS-sponsored work) of limited or transitory interest.

Federal Information Processing Standards Publications. This series is the official publication within the Federal Government for information on standards adopted and promulgated under the Public Law 89-306, and Bureau of the Budget Circular A-86 entitled, Standardization of Data Elements and Codes in Data Systems.

Consumer Information Series. Practical information, based on NBS research and experience, covering areas of interest to the consumer. Easily understandable language and illustrations provide useful background knowledge for shopping in today's technological marketplace.

\section{BIBLIOGRAPHIC SUBSCRIPTION SERVICES}

The following current-awareness and literature-survey bibliographies are issued periodically by the Bureau:

Cryogenic Data Center Current Awareness Service (Publications and Reports of Interest in Cryogenics). A literature survey issued weekly. Annual subscription: Domestic, $\$ 20.00$; foreign, $\$ 25.00$.

Liquefied Natural Gas. A literature survey issued quarterly. Annual subscription: $\$ 20.00$.

Superconducting Devices and Materials. A literature survey issued quarterly. Annual subscription: $\$ 20.00$. Send subscription orders and remittances for the preceding bibliographic services to the U.S. Department of Commerce, National Technical Information Service, Springfield, Va. 22151.

Electromagnetic Metrology Current Awareness Service (Abstracts of Selected Articles on Measurement Techniques and Standards of Electromagnetic Quantities from D-C to Millimeter-Wave Frequencies). Issued monthly. Annual subscription: $\$ 100.00$ (Special rates for multi-subscriptions). Send subscription order and remittance to the Electromagnetic Metrology Information Center, Electromagnetics Division, National Bureau of Standards, Boulder, Golo. 80302.

Order NBS publications (except Bibliographic Subscription Services) from: Superintendent of Documcnts, Government Printing Office, Washington, D.C. 20402. 
U.S. DEPARTMENT OF COMMERCE

National Bureau of Standards

Washington, D.C. 20234

POSTAGE AND FEES PAID

OFFICIAL BUSINESS

Penalty for Private Use, $\$ 300$
U.S. DEPARTMENT OF COMMERCE COM-215 